\title{
Green Synthesis, Characterization and Antibacterial Activity of Silver Nanoparticles from Capparis Spinosa Leaf Extract
}

\author{
SALEH H. SALMEN ${ }^{*}$, EMAN DAMRA ${ }^{1}$, TAHANI AWAD ALAHMADI ${ }^{2}$, \\ SULAIMAN ALI ALHARBI ${ }^{1}$ \\ ${ }^{1}$ Department of Botany and Microbiology, College of Science, King Saud University P.O. Box 2455.Riyadh-11451, Saudi \\ Arabia \\ ${ }^{2}$ Department of Pediatrics, College of Medicine, King Saud University [Medical City], King Khalid University Hospital, PO \\ Box 2925, Riyadh, 11461, Saudi Arabia
}

\begin{abstract}
The current study reports the green synthesis of silver nanoparticles (AgNPs) using Capparis spinosa leaf extract acting as a capping and reducing agent. The characterization of AgNPs was confirmed using ultraviolet-visible spectrophotometry (UV-Visible), fourier transform infrared spectroscopy (FTIR), energy-dispersive X-ray spectroscopy (EDX), and transmission electron microscopy (TEM). The plant extract used reduces Ag+ into AgNPs within a few minutes as indicated by the changed color, from yellow to reddish-brown. The UV-vis spectrum of AgNPs appeared a characteristic surface plasmon resonance peak at 400-450 $\mathrm{nm}$. FTIR spectroscopy confirmed the role of plant extract as a reducing and capping agent of silver ions. The spectra of FTIR revealed a broad transmission peaks from 3412 to $617 \mathrm{~cm}^{-1}$. An EDX analysis signal at $3 \mathrm{keV}$ and weight $65.38 \%$ showed the peak to be in the silver region, a fact which was confirmed by the presence of elemental silver. Under TEM, the nanoparticles were seen to be spherical, with an average particle size of $13 \mathrm{~nm}$. AgNPs showed antibacterial activity against $S$. epidermidis, S. aureus, MRSA and E. coli. The inhibition zones for $S$. epidermidis and $S$. aureus were 8 to $10 \mathrm{~mm}$, while MRSA is 7 to $10 \mathrm{~mm}$. The inhibition zone of E. coli was higher at 10 to $13 \mathrm{~mm}$.
\end{abstract}

Keywords: Plant, AgNPs, Capparis spinose, Antibacterial activity, Green synthesis, Nanotechnology

\section{Introduction}

In recent years, nanotechnology has emerged as an important research area due to its application in electrical engineering, molecular diagnostics, drug delivery, medicine, electronics and optics, amongst others. The term "nanoparticle" refers to a particle with a size between $1 \mathrm{~nm}$ and $100 \mathrm{~nm}$ [1]. Nano-size enhances the surface-to volume ratio and the particles exhibit chemical, physical and biological properties which often differ markedly from the original bulk material [2]. Nanoparticles can be categorized into organic-nanoparticles, such as fullerenes and inorganic nanoparticles composed of silver, gold, zinc oxide and titanium oxide. AgNPs have been used in the field of nanotechnology because of their distinct properties, including strong conductivity, chemically stability, catalytic activity, anti-cancer activity and antibacterial and antifungal activity [3-9]. Due of their unique properties, AgNPs are widely used in several applications, including medicinal, agriculture, health care, consumer, diagnostics, optical sensors and technological purposes [10-14]. Silver has interesting material properties and is a natural resource that is cheap and abundant [15]. AgNPs have been found to exhibit antimicrobial activity, presumably by releasing ionic silver which inactivate thiol groups leading to a) the denaturation of bacterial enzymes, b) the disruption of cellular cytoplasm, c) the inhibition of bacterial DNA replication and finally to a decrease in ATP levels and ultimately cell-death [16].

Capparis spinose is a perennial shrub belonging to the genus Capparis and the family Capparaceae [17-19]. It is distributed in a variety of habitats from subtropical to tropical regions [19]. While a native of the Mediterranean it is widely distributed, from the Atlantic coast of the Canary Islands and Morocco to the Black Sea, the Crimea and Armenia. It can also be found in Iran and the Arabian Peninsula, notably Yemen and Saudi Arabia [20, 21, 17]; such widespread distribution is due to the plants resistance to a

\footnotetext{
*email: ssalmen@ksu.eda.sa
} 
range of biotic and abiotic stresses [17]. A range of plants, bacteria, algae and fungi can be used for AgNPs biosynthesis [22]. Several studies reported AgNPs synthesis using plants such as Mangifera indica [23], Tinospora cordifolia (Thunb.) [24], Solanum indicum L. [25], Acorus calamus [26], Sunroot [27], Indigofera oblongifolia [28], Aloe fleurentiniorum [29], Amorphophallus paeoniifolius [30], Malus domestica [31]. Moreover, other biological sources of AgNps synthesis are also available, such as cow milk [32], Cottonseed Oilcake [33], vegetable waste [34], coconut (Cocos nucifera) oil [35], Spirulina microalgae [36], seaweed Spyridia filamentosa [37]. Such biological sources act rapidly, are non-toxic, cost-effective, pollution-free and therefore eco-friendly [38,39]. Capparis spinosa exhibits a variety of potential pharmacological properties, being antimicrobial and possessing antioxidant, anticancer and hepatoprotective properties [40-45]. It is widely used in Arab medicine to treat gastrointestinal problems, rheumatism, headache, liver and kidney problems, convulsions, paralysis, gum problems and finally as an antimalarial agents $[46,47,21,25]$

The aim of this study was to synthesize silver nanoparticles using extracts of $C$. spinosa leaves. The characterization of variously synthesized AgNPs is described, as is their antibacterial activity against a range of pathogenic bacteria.

\section{Materials and methods}

\section{Plant collection and preparation of leaf extract}

Fresh leaves of $C$. spinosa were collected from Yemen, washed 2-3 times with tap water, rinsed with distilled water and kept it in the dark until completely air dried. A sample (10 g.) of leaf powder was then added to deionized water $(100 \mathrm{ml})$ and boiled with stirring for $10 \mathrm{~min}$. After boiling, the mixture was cooled and filtered using Whatman filter paper No 1, the size was $125 \mathrm{~mm}$ (Whatman international Limited, England). The supernatant was finally stored at $4^{\circ} \mathrm{C}$ until used.

\section{Biosynthesis of AgNPs}

An aqueous solution of silver nitrate (Sigma-Aldrich, USA) $0.01 \mathrm{mM}$ was used for the preparation of AgNPs. Ten milliliters of the aqueous plant extract were added to $100 \mathrm{~mL}$ silver nitrate with constant stirring at $25^{\circ} \mathrm{C}$ until the color changed to dark brown (indicating evidence to AgNPs formation). Then, using centrifugation, the synthesized AgNPs were separated for 20 min at 13,000 rpm. The resultant AgNPs were then heated at $40^{\circ} \mathrm{C}$ for $2 \mathrm{~h}$ until completely dry.

\section{UV-Visible spectroscopy analysis}

UV-Vis spectroscopy at wavelengths ranging from 300 to $800 \mathrm{~nm}$ (using an Ultrospec 2100 Pro UV/visible spectrophotometer) (Biochrom, UK) was used to record the formation of AgNPs in mixture.

\section{FTIR analysis}

FTIR analysis was used to determine functional groups in $C$. spinosa extract that might accountbe for the synthesis of AgNPs. FTIR analysis was achieved using a FTIR spectrometer, Nicolet iS50 (Thermo Fisher Scientific, Waltham, MA, USA). The samples were mixed with KBR (FTIR grade) and scanned on FTIR at resolution of $4 \mathrm{~cm}^{-1}$ and over the range of $4000-400 \mathrm{~cm}^{-1}$. The resultant spectrum was then compared with a reference chart to identify functional groups present in sample.

\section{SEM and EDS analysis}

SEM investigation of dehydrated samples was achieved by mounting nanoparticles on sample stubs with double adhesive tape and covered with gold in a sputter coater and observed at $10 \mathrm{kV}$ uisng JSM6380 LA microscope (JEOL, Japan) and EDS examination was performed using an Altima IV device (Regaku, Japan). 


\section{TEM analysis}

TEM analysis was used to determine size the surface morphology of AgNPs. Samples for TEM investigation were done on carbon-coated copper TEM grids. The films on the TEM grids were allowed to stand for $2 \mathrm{~min}$, the extra solution was removed using a blotting paper, and the grid was allowed to dehydrated previous to measurement. TEM investigation were noted at $80 \mathrm{kV}$ using by a JEOL-JEM1011 instrument.

\section{Antibacterial studies}

The bacteria used in this study were obtained from King Saud University's Microbiology Laboratory. S. aureus, S. epidermidis, MRSA and E.coli were inoculated onto Nutrient Agar Medium (SigmaAldrich, India) and incubated for 18 hours at $37^{\circ} \mathrm{C}$.

\section{Antibacterial properties}

The antibacterial effect of AgNPs was determined using antibiotic sensitivity discs. Mueller Hinton Agar Medium almost $20 \mathrm{mls}$ (Sigma-Aldrich) was poured in Petri dishes and inoculated with each bacterium $\left(1 \times 10^{6} \mathrm{cfu} / \mathrm{ml}\right)$. Then, $100 \mu \mathrm{L}$ from synthesized nanoparticles were added to each disc (Bank Disk, Arab Company for Medical Diagnostics, Jordan), and the plates were incubated at $37^{\circ} \mathrm{C}$ for $18 \mathrm{~h}$. The presence of inhibition zones indicated an antibacterial effect; distilled water was used as a control.

\section{Statistical analysis}

Triplicates were used and the results subjected to one-way analysis using SPSS statistical software (SPSS Inc., USA), A P-value $<0.05$ indicated a statistical significant result.

\section{Results and discussions Visual observations}

The synthesis of AgNPs was indicated by the color change when mixing the solution; after two hours of incubation, the color of the reaction mixture changed to a light yellow to reddish brown. No similar color changes were seen in the control silver nitrate solution without leaf extract. Such color changes result from the oscillations of free electrons in the reaction mixture of the resultant nanoparticles [33, 34].

\section{UV-Visible Spectral Analysis}

The detection of the reduction in silver ions into silver nanoparticles was observed by the resultant color change over time using a UV-visible spectrophotometer. The absorption peaks of synthesized AgNPs using extracts of $C$. spinose occurred at 350 to $400 \mathrm{~nm}$ (Figure 1). Wave peaks confirmed the formation of Ag nanoparticles in the mixture [35, 36,34].

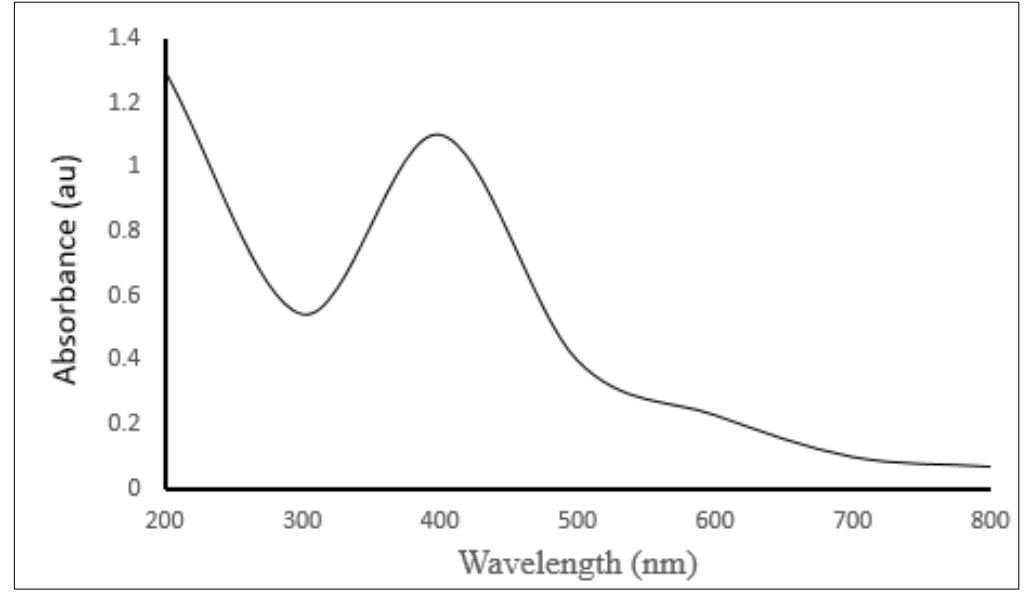

Figure 1. UV-absorption spectrum of the AgNPs biosynthesized using $C$. spinosa leaf extract 


\section{FTIR analysis}

FTIR spectroscopy is suitable for surface chemical characterization. FTIR spectra of AgNPs indicated the presence of potential bioactive compounds in the plants extracts, that were responsible for the silver ion reducing agent and its interaction with the AgNPs (Figure 2). The spectra revealed a broad transmission peak from 4000 to $400 \mathrm{~cm}^{-1}$. The first peak at $3412.06 \mathrm{~cm}^{-1}$, resembles the hydrogen bonded hydroxyl group ( $\mathrm{H}$ and $\mathrm{O}-\mathrm{H}$ stretch) of phenols and alcohols [37]. The next peak at $2923.81 \mathrm{~cm}^{-1}$ indicates the alkane stretching band, while peak at $1633.34 \mathrm{~cm}^{-1}$ resembles to $\mathrm{C}=\mathrm{C}$ stretch, which refers alkenes $\mathrm{A}$ peak at $1384 \mathrm{~cm}^{-1}$ corresponds to sulphonates, while that at $1109.44 \mathrm{~cm}^{-1}$ resembles to C-O. The final peak, at $617.40 \mathrm{~cm}^{-1}$, corresponds to $\mathrm{C}=\mathrm{N}$ stretch, indicating aliphatic amines.

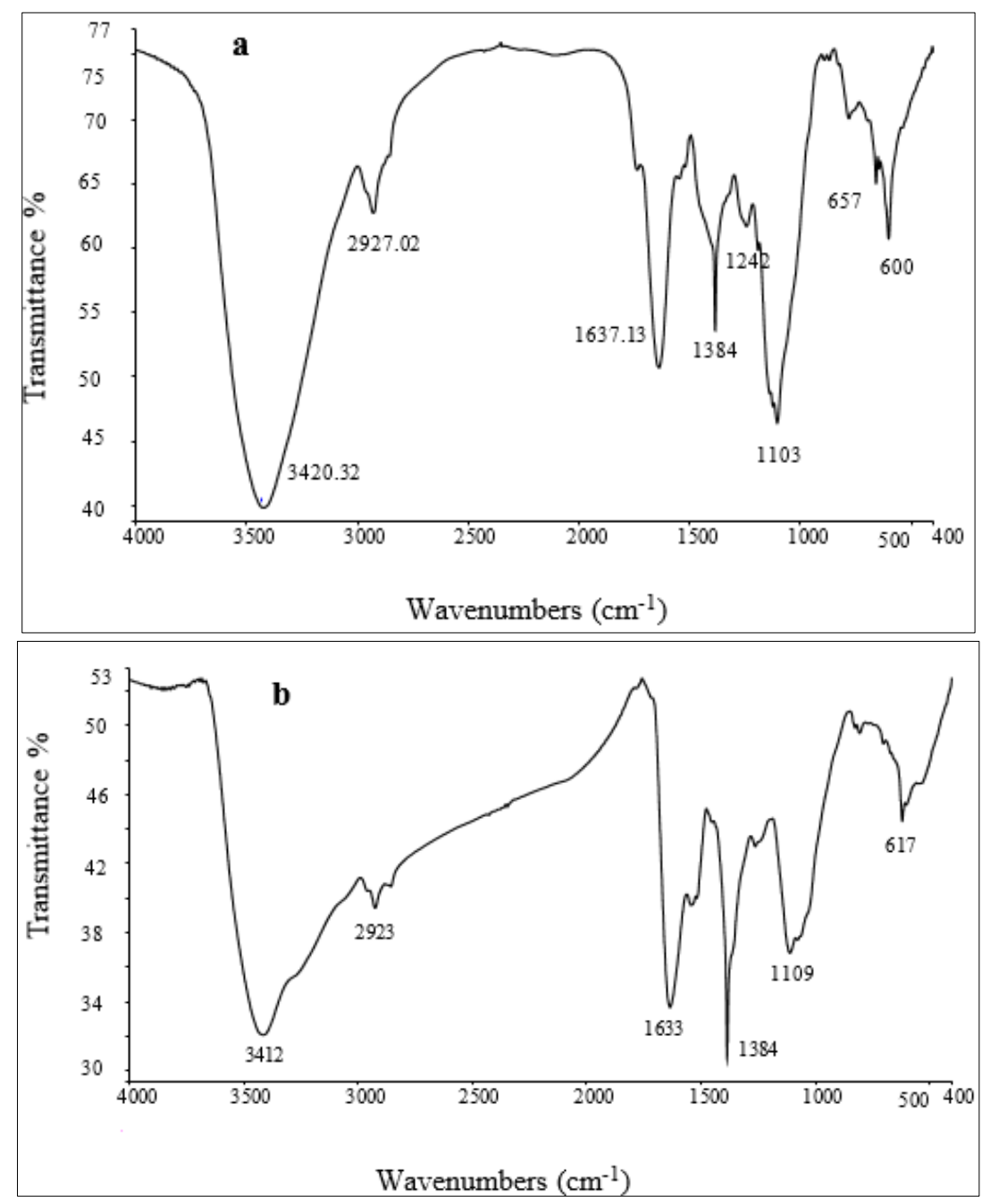

Figure 2. FTIR spectra of the C. spinosa extract (A) and AgNPs produced using the $C$. spinosa leaf extract (B)

\section{SEM, TEM and EDS analysis}

AgNPs synthesized by using $C$. spinosa aqueous leaf extract was observed using SEM and TEM analysis in order to determine the shape of the nanoparticles (Figure 3,4). The synthesized AgNPs were spherical, with the diameter of nanoparticles ranging from 5 to $27 \mathrm{~nm}$ and the average particle size being circa $13 \mathrm{~nm}$. EDS analysis confirmed the presences of Ag elements in the AgNPs. The optical absorption peak was observed at $3 \mathrm{Kev}$. The AgNPs reduced by the $C$. spinose have the weight percentage of silver as $65.38 \%$ (Figure 5). The results of previous studies of AgNPs biogenically synthesized from C. spinosa extracts showed similar results [48-51,35,36] as do a variety of AgNPs synthesized using other plants 
extracts, such as Aloe vera, Portulaca oleracea and Cynodon dactylon [51]; Indigofera oblongifolia [35]; Aloe fleurentiniorum [36].

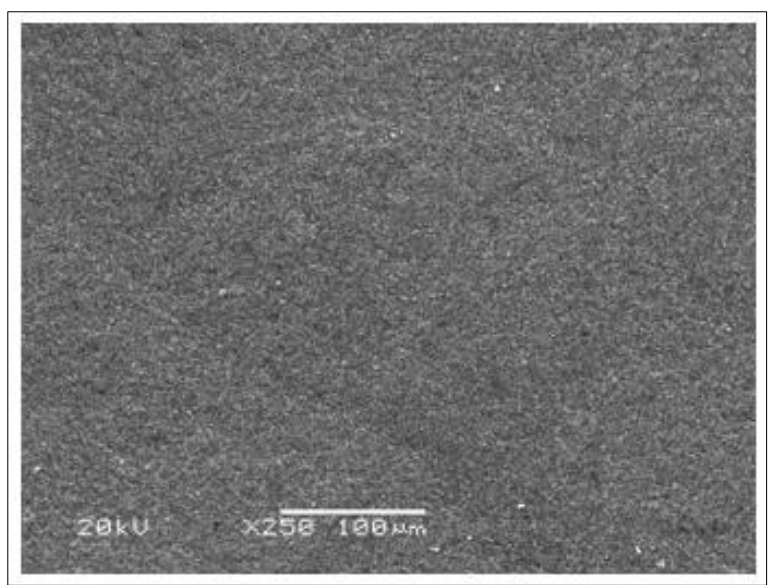

Figure 3. SEM images of AgNPs synthesized by $C$. spinose. Scale bar represents $100 \mu \mathrm{m}$

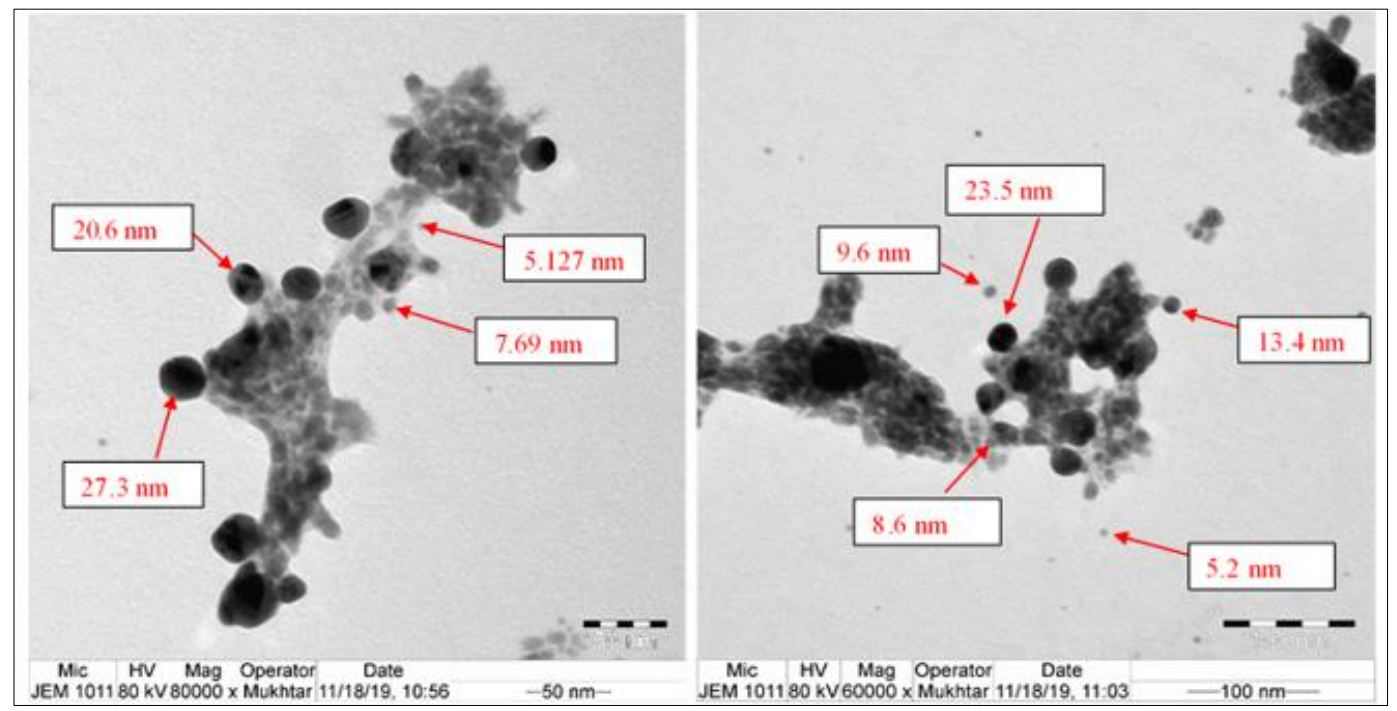

Figure 4. TEM image of AgNPs synthesized using $C$ spinosa leaf extract

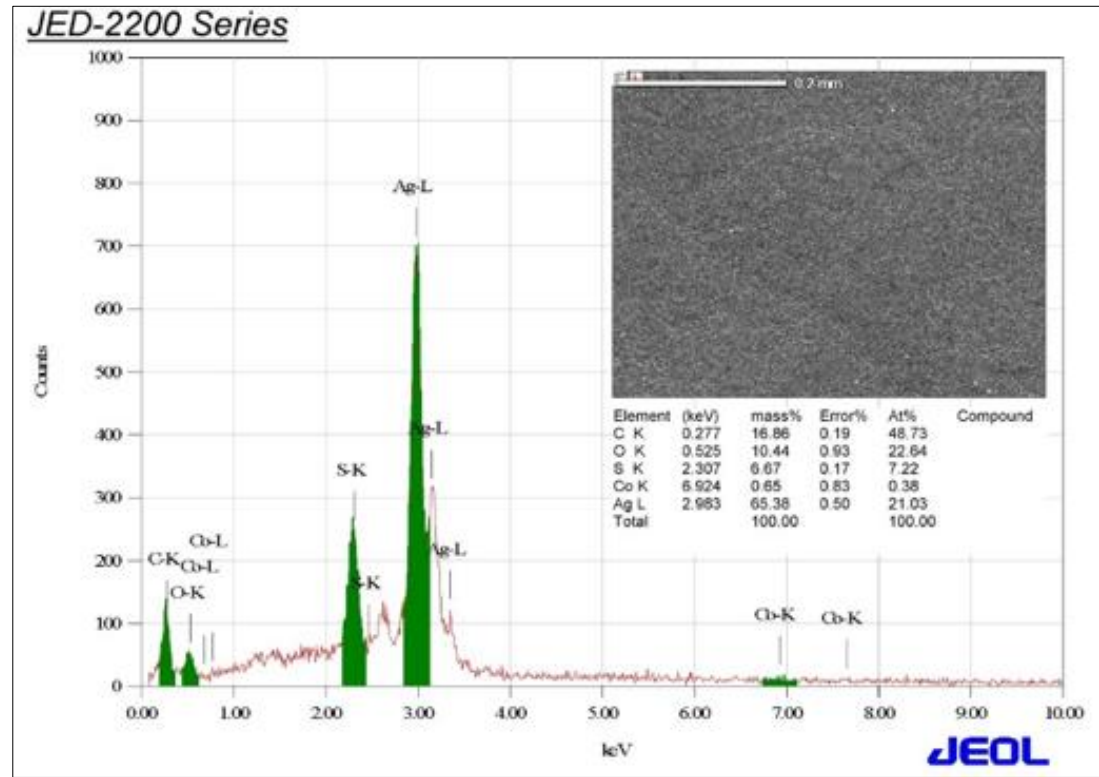

Figure 5. EDS of AgNPs synthesized by $C$. spinose.

The horizontal axis displays the energy in $\mathrm{KeV}$, while the vertical axis shows the number of $\mathrm{X}$-ray counts 


\section{Antimicrobial Activity}

The results show that the $C$. spinose synthesized AgNPs exhibited antibacterial activity against $S$. epidermidis, $S$. aureus, MRSA and E. coli (Table 1). Inhibition zones of 8-10 mm for $S$. aureus and $S$. epidermidis, 7- $10 \mathrm{~mm}$ for MRSA, and 10-13mm for Escherichia coli were recorded. The results are comparable to those reported by other workers [52-54].

Table 1. Antibacterial activity of silver nanoparticles (AgNPs) against pathogenic bacteria

\begin{tabular}{|c|c|c|c|}
\hline \multirow{2}{*}{ Bacteria } & & \multicolumn{2}{|c|}{ Inhibition zone (mm) } \\
\cline { 2 - 4 } & AgNPs $(1 \mathrm{mg})$ & AgNPs $(2 \mathrm{mg})$ & Control \\
\hline S. epidermidis & $8 \pm 0.5^{*}$ & $10 \pm 0.0$ & $0 \pm 0.0$ \\
\hline S.cuureus & $8 \pm 0.0$ & $10 \pm 0.0$ & $0 \pm 0.0$ \\
\hline MRSA & $7 \pm 0.0$ & $10 \pm 0.1$ & $0 \pm 0.0$ \\
\hline E. coli & $10 \pm 0.1$ & $13 \pm 0.1$ & $0 \pm 0.0$ \\
\hline
\end{tabular}

*Numbers are mean \pm SD

\section{Conclusions}

This study reports simple, rapid, inexpensive and eco-friendly a method for green synthesis of AgNPs using a $C$. spinose leaf extract. The synthesized AgNPs were confirmed using UV-Visible, FTIR, EDX, and TEM. The AgNPs synthesized were mainly spherical in shape with an average particle size of 13 $\mathrm{nm}$ and elemental composition confirmed the significant existence of $\mathrm{Ag}$ without any other the contaminants. The biosynthesized AgNPs have demonstrated strong antibacterial potential and can therefore be used as an antibacterial agent against $E$. coli, S. aureus, S. epidermidis and MRSA.

Acknowledgment.This project was supported by Researchers Supporting Project number (RSP2020/230), King Saud University, Riyadh, Saudi Arabia.

\section{References}

1.DAHL, J.A., MADDUX, B.L.S., HUTCHISON, J.E. Chem. Rev. 107, no. 6, 2007, p. 2228.

2.CAO, G., WANG, Y. "Nanostructures \& Nanomaterials: Synthesis, Properties and Applications," World Scientific Pub. London, Imperial College Press, 2011.

3.CHEN, Y.Y., WANG, C.A., LIU, H.Y., QIU, J.S., BAO, X.H. Chem.Comm, 37, 2005, p. 5298.

4.LI, Z., LEE, D., SHENG, X. ROBERT, E.C. MICHAEL, F.R. Langmuir. 22, no. 24, 2006, p.9820.

5.SETUA, P., CHAKRABORTYM, A., SETH, D., BHATTA, M.U., SATYAM, P.V., SARKAR, N. J. Phys. Chem. C. 111, no.10, 2007, p.3901.

6.LAW, N., ANSARI, S., LIVENS, F.R., RENSHAW, J.C., LLOYD, J.R. Microbiol Environ. Appl., 74, 2008.p.7090.

7.VIJAYARAGHAVAN, K., KAMALA NALINI, S.P., PRAKASH, N.U., MADHANKUMARM, D. MATER LETT. 75, 2012, p.33.

8.JEYARAJ, M., RAJESHM, M., ARUN, R., ALI, D.M., SATHISHKUMAR, G., SIVANANDHANA, G.,DEVA, G.K., MANICKAVASAGAMA, M., PREMKUMAR, K., THAJUDDINC, N., GANAPATHI, A. Colloid Surf. B-Biointerfaces. 1, 2013, p.708.

9.CHOKRIWAL, A., MADAN, M.S. ABHIJEET, S. Am. J. Pharm.Tech. Res. 4, no.6, 2014, p.38. 10.GURUNATHAN, S., PARK, J.H., HAN, J.W., KIM, J.H. Int J Nanomedicine. 10, 2015, p.4203. 11.WEI, L., LU, J., XU, H., PATEL, A., CHEN, Z., CHEN, G. Drug Discov Today. 20, 2015, p.595. 12.LI, W.R., XIE, X.B., SHI, Q.S., ZENG, H.Y., OU-YANG, Y.S., CHEN, Y.B. Appl Microbiol Biotechnol. 85, 2010, p.1115.

13.MUKHERJEE, P., AHMAD, A., MANDAL, D., SENAPATI, S., SAINKAR, S.R., KHAN, M.I., RENU, P., AJAYKUMAR, P.V., ALAM, M., KUMAR, R., SASTRY, M. Nano Letters. 1, 2001.p.515. 
14.CHERNOUSOVA, S., EPPLE, M. Angewandte Chemie International Edition. 52, 2013, p.1636. 15.WANG, L., ZHANG, T., LI, P., HUANG, W., TANG, J., WANG, P., LIU, J., YUAN, Q., BAI, R., LI, B., ZHANG, K., ZHAO, Y., CHEN, C. ACS Nano, 9, no.6, 2015, p. 6532.

16.FENG, Q.L., WU, J., CHEN, G.Q., CUI, F.Z. KIM, T.N., KIM, J.O. J Biomed Mater Res., 52, no.4, 2000 , p.662.

17.TLILI, N., EL-FALLAH, W., SAADADOUI, E., KHALDI, A.H., TRIKI, S., NASRI, N. Fitoterapia, 82, 2011, p.93.

18.HALL, C.J. SYSTMA, J.K., ILTIS, H.H. Am J Bot., 89, no.11, 2002.p.1826.

19.INOCENCIO, C., RIVERA, D., OBON, C., ALCARAZ, F., BARRENA, J.A. ANN. MISSOURI BOT. GARD. 93, 2006. p.122.

20.INOCENCIO, C., AlCARAZ, F., CALDERON, F., OBON, C., RIVERA, D. Eur Food Res Technol., 214, 2002, p.335.

21.RIVERA, D., INOCENCIO, C., OBON, C., ALCARAZ, F. Economic Botany, 57, no.4, 2003. p.515. 22.GEETHALAKSHMI, R., SARADA, D.V.L. I. J. Eng. Sci. Techn., 2, no. 5, 2010, p.970.

23.AMEEN, F., SRINIVASAN, P., SELVANKUMAR, T., KAMALA-KANNAN, S., AL NADHARI, S., ALMANSOB, A., DAWOUD, T., GOVARTHANAN, M. Bioorg Chem., 88, 2019, 102970.

24.SELVAM, K., SUDHAKAR, C., GOVARTHANAN, M., THIYAGARAJAN, P., SENGOTTAIYAN, A., SENTHILKUMAR, B., SELVANKUMAR, T. J. Radiation Res. Appli. Sci., 10, 2017.p.6.

25.SENGOTTAIYAN, A., MYTHILI, R., SELVANKUMAR, T., ARAVINTHAN, A., KAMALAKANNAN, S., MANOHARAN, K., THIYAGARAJAN, P., GOVARTHANAN, M., KIM, J. Res. Chemical Intermedi., 42, 2016.p.3095.

26.SUDHAKAR， C., SELVAM， K., GOVARTHANAN, M., SENTHILKUMAR, B., SENGOTTAIYAN, A. STALIN, M., SELVANKUMAR, T. J., Genetic Engineering Biotech. 13, no.2, 2015.p. 93.

27.ARAVINTHAN, A., GOVARTHANAN, M., SELVAM, K., PRABURAMAN, L., SELVANKUMAR, T., BALAMURUGAN, R., KAMALA-KANNAN, S. KIM, J. Int J Nanomedicine, 10. 2015.p.1977.

28.SALMEN, S.H., ALWHIBI, M.S., ALHARBI, S.A. Appl. Ecol. Environ. Res., 17, no. 6, 2019, p. 12869.

29.SALMEN, S.H., ALHARBI, S.A. Green Chem. Lett. Rev., 13, no. 1, 2020.p.1.

30.GOMATHI, M., PRAKASAM, A., RAJKUMAR, P.V. J. Clust. Sci., 30, 2019. p.995.

31.ANANDA, M.A., VINAYAGAMA, R., VIJAYAKUMARA, S., BALUPILLAIA, A., HERBERTB, F.J., KUMARB, S., GHIDANC, A.Y., AL-ANTARYC, T.M., DAVID, E., Microb.Pathog.,135, 2019.1036092.

32.LEE, K. PARK, S., GOVARTHANAN, M., HWANG, P., SEO, Y., CHO, M., LEE, W., LEE, J., KAMALA-KANNAN, S., OH, B. Mater. Lett., 105, 2013, p.128.

33.GOVARTHANAN, M., CHO, M., PARK, J., JANG, J., YI, Y., KAMALA-KANNAN, S., OH, B. J. Nanomater. 2016, Article ID 7412431.

34.MYTHILI, R., SELVANKUMAR, T., KAMALA-KANNAN, S., SUDHAKAR, C., AMEEN, F., AL-SABRI, A., SELVAM, K., GOVARTHANAN, M., KIM, H. Mater. Lett., 225, 2018, p.101.

35.GOVARTHANANA, M., SEOA, Y., LEEA, K., JUNGA, I., JUB, H., KIMB, J., CHOA, M., KAMALA-KANNANA, S., OHA, B. Artif. Cell. Nanomed. Biotechnol., 44, no.8, 2016, p.1878.

36.MUTHUSAMY, G., THANGASAMY, S., RAJA, M., CHINNAPPAN, S., KANDASAMY, S. Environ Sci Pollut Res., 24, 2017.p.19459.

37.VALARMATHI, N., AMEEN, F., ALMANSOB, A., KUMAR, P., ARUNPRAKASH, S., GOVARTHANAN, M., Mater. Lett., 263, 2020, 127244.

38.ZHANG, S., HU, D.B., HE, J.B., GUAN, KY., ZHU, H.J., Tetrahedron, 70, no.4, 2014.p.869.

39.AHMED, S., AHMAD, M., SWAMI, B.L. IKRAM, S.A. J., Advanced Res., 7, 2016, p.17. 40.MISHRA, S.N., TOMAR, P.C., LAKRA, N., Indian J. Tradit. Knowl, 6, no.1, 2007, p. 230. 
41.TESORIERE, L., BUTERA, D., GENTILE, C., LIVREA, M.A. J Agric Food Chem., 55, no.21, 2007.p. 8465.

42.LAM, S.K., NG, T.B. Phytomedicine, 16, 2009.p.444.

43.AGHEL, N., RASHIDI, I., MOMBEINI, A. Iran J Pharm Res., 6, no.4, 2007.p.285.

44.TLILI, N., KHALDI, A., TRIKI, S., MUNNÉ-BOSH, S., Plant Foods Hum Nutr., 65, no.3, 2010.p. 260.

45.GULL, T., ANWAR, F., SULTANA, B., ALCAYDE, C.A.M., NOUMAN, W. Ind. Crop. Prod., 67, 2015.p.81.

46.MIRALDI, E., FERRI, S., MOSTAGHIMI, V. J., Ethnopharmacol., 75, no.2-3, 2001. p.77.

47.EDDOUKS, M., LEMHARDI, A., MICHELB, J.B. J., Ethnopharmacol., 94, no.1, 2004, p.143.

48.NADAGOUDA, M.N., SPETH, T.F., VARMA, R.S., Acc. Chem. Res., 44, no.7, 2011, p.469.

49.KHAN, M., KHAN, S.T., KHAN, M. ADIL, S. F., MUSARRAT, J., AL-KHEDHAIRY A. A., ALWARTHAN A., SIDDIQUI, M.R.H., ALKHATHLAN, H. Z Int J Nanomedicine, 9, 2014.p.3551.

50.SALEHI, S., SHANDIZ, A.S., GHANBAR, F., DARVISH, M.R., ARDESTANI, M.S., MIRZAIE, A., JAFARI, M. Int J Nanomedicine, 29, 2016.p.1835.

51.TARAD, A.A., ALHARBI, S.A., SALMEN, S.H. WAINWRIGHT, M. Biotechnol. Biotechnol, Equip., 31, no.2 2017, p.411.

52.PUISO, J., EJONKUVIENE, D., MACIONIENE, I., SALOMSKIENE, J., JASUTIENE, I., KONDROTAS, R. Colloid Surf. B-Biointerfaces, 121, 2014.p.214.

53.MATINISE, N., KAVIYARASU, K., MONGWAKETSI, N., KHAMLICH, S., MAAZA, M. Appl. Surf. Sci., 446, 2018.p. 66.

54.PREMKUMARA, J., SUDHAKARA, T., DHAKALA, A., BABU SHRESTHAA, J.B., KRISHNAKUMARA, S., BALASHANMUGAM, P. Biocatal. Agric. Biotechnol, 15, 2018.p.311

Manuscript received: 7.12 .2020 